Original Research

\title{
Diabetic Foot Spa Implementation in Early Neuropathy Diagnosis Based on Blood Glucose Levels, Foot Sensitivity and the Ankle Brachial Index in Patients with Diabetes Mellitus
}

\section{Erika Martining Wardani, Chilyatiz Zahroh and Nur Ainiyah}

University of Nahdlatul Ulama Surabaya, Indonesia

\begin{abstract}
Introduction: Diabetes Mellitus (DM) is a cause of morbidity mainly due to vascular complications. The prevention of diabetic foot problems can be done through metabolic control and foot exercises. The purpose of this study was to determine the effect of diabetes foot spa measures on blood glucose levels, foot sensitivity and the ankle brachial index.

Methods: This research was a pre-experimental design. The population totaled 170 DM patients and the sample was finalized at 30 respondents. The independent variable was diabetic foot spa, while the dependent variables were blood glucose levels, blood sensitivity and the ankle brachial index. The data was analyzed using a t-test and Wilcoxon rank test.

Results: Diabetic foot spa in early neuropathy detection testing has a blood glucose level of $\mathrm{t}=9.523$ and a $\mathrm{p}$ value $=0.000$. Diabetic foot spa also significantly affects foot sensitivity with a $\rho<\alpha(0.001<0.05)$ and an ankle brachial index of $(\mathrm{ABI}) \rho<\alpha(0.008$ $<0.05$ ).

Conclusion: Diabetic foot spa conducted regularly and independently can reduce the level of complications in Diabetes Mellitus patients. Furthermore, the tingling and pain in the feet can be reduced or even disappear as well as preventing complications such as foot ulcers that can often become amputations.
\end{abstract}

\section{ARTICLE HISTORY}

Received: Oct 05, 2018

Accepted: Oct 29, 2019

\section{KEYWORDS}

ankle brachial index; blood glucose levels; diabetic foot spa; diabetes mellitus; foot sensitivity

\section{CONTACT}

Erika Martining Wardani $\triangle$ erika@unusa.ac.id

$\equiv$ University of Nahdlatul Ulama Surabaya, Indonesia

Cite this as: Wardani, E., M., Zahroh, C., \& Aniyah, N. (2019). Diabetic Foot Spa Implementation in Early Neuropathy Diagnosis Based on Blood Glucose Levels, Foot Sensitivity and the Ankle Brachial Index in Patients with Diabetes Mellitus. Jurnal Ners, 14(1), 106-110. doi:http://dx.doi.org/10.20473/in.v14i1.9950

\section{INTRODUCTION}

Diabetes Mellitus is one of the metabolism disorders that is very common in the world. Urbanization has led to histrionic changes in lifestyle, especially in developing countries with rapid transitions along with an increase in the risk factors of noncommunicable disease such as DM. Diabetes Mellitus type 2 can cause various complications for the patients, either acute or chronic. The chronic complications that can occur include motor neuropathy and vascular peripheral disease. Almost $60 \%$ of patients suffer from these complications (Black \& Hawks, 2014).

Complications can cause an obstruction of blood flow to organs via microangiopathy and macroangiopathy (Smeltzer \& Bare, 2001). DM patients with gangrene often require amputations. DM patients have a higher chance of experiencing lower leg amputations; up to 15 times more than those without DM (Greenstein \& Wood, 2010). The International Diabetes Federation has shown that 382 million people are suffering from DM to date. The amount will increase to become 592 million people in 2035. Out of this amount, 175 million people are unaware of their condition. More than $80 \%$ of ailed people are living in a low earning country and are from the middle class.

The incidence of DM in the age range of $40-59$ years old in 2014 reached 387 million people. This number is expected to increase to 529 million by 2035 (International Diabetes Federation) [IDF], 2013). According to (IDF, 2013), there are 9.1 million DM cases in Indonesia. The high rate of DM in Indonesia has positioned Indonesia as having the largest number of DM cases in the world after China, India, Brazil, and the United States (IDF, 2013). 
Based on the 2012 Annual Hospital Report, the largest number of outpatients (as of May 31 ${ }^{\text {st }}, 2013$ ) in type B and C hospitals in East Java was for DM $(137,427$ cases). The highest number of inpatients in hospitals B and C was for DM (17,990 cases) (Riskesdas, 2018). DM in Surabaya has seen an increase in the number of cases from 15,961 in 2009 to 21,729 in 2010 . Then it increased to 26,613 in 2011. Thus, the number of DM patients has increased from 2009 - 2011. In 2012, it increased to 21,268 cases (Riskesdas, 2018).

Diabetic foot prevention can be done through metabolism control that places an emphasis on nutritional status, blood glucose levels, vascular control by doing foot exercises and non-invasive vascular examinations such as the ankle brachial index, toe pressure, and ankle pressure checks regularly. This is as well as the modification of the risk factors such as quitting smoking and putting on special footwear (Ganong, 2008).

There are various ways to prevent, cure, and control the complications that are a part of DM characteristics (Tang, et al., 2013), manage stress, because stress can increase glucose level (Bistara, et al., 2019) and dietary compliance (Bistara \& Ainiyah, 2017). Foot treatment for DM patients can prevent the risk of diabetic foot ulcers (Mahfud, 2012). Foot care or foot treatment is one factor which can affect peripheral blood circulation. Diabetic foot spa is a foot care series in which the activities include foot exercises, warm water cleansing and massage (Purwanti, 2013). Regular foot care can reduce the number of amputations by around 50\% (Windasari, 2015). This is according to the program of DM control in Indonesia, which is focused on controlling the risk factors to reduce the number of illnesses, deformity and death that are caused by DM (PERKENI, 2011).

Related research with the title 'The effect of foot exercises on the blood glucose level of Diabetes Mellitus patients type II'. This was conducted in Cawas public health center with the result that there is an effect from foot exercises on the blood glucose level of the Diabetes Mellitus type II patient (Eraydin \& Avsar, 2017).

Warm water therapy is useful to improve blood circulation, to reduce muscle tone stiffness, to activate relaxed feeling and to stimulate the nerve endings to create a refreshing feeling (Suandika, 2016). Warm compress also as pain release (Zahroh \& Faiza, 2018). This study has the purpose of determining the effect of diabetic foot spa actions on blood glucose levels, foot sensitivity and the ankle brachial index.

\section{MATERIALS AND METHODS}

The design of this study was a pre-experiment, which the researcher measures blood glucose levels, foot sensitivity, Ankle Brachial Index (ABI) scores before and after the Diabetic Foot Spa intervention. The population of this research totaled 170 respondents. The samples were obtained through probability sampling (simple random sampling technique) focused initially on 30 respondents. The blood glucose level measurement, foot sensitivity, and ABI score was taken before and after the intervention. The patients with DM type II were from Waru Health Center Sidoarjo.

The data process began from taking permission to conduct the research. To determine the neuropathy diagnosis, the researcher used the medical record available from the public health center. The number of samples used in each intervention and control group totaled 30 people who met the inclusion criteria, namely type 2 DM patients who did not have lower limb complications such as diabetic ulcers, no broken bones in the legs, in the age range of $41-60$ years old, with a blood glucose level that was less than $600 \mathrm{mg} \%$, where they had had Diabetes Mellitus for less than 5 years, and where they had no chronic disease.

The diabetic foot spa consists of various activities such as diabetic foot exercises before the foot spa is conducted, skin cleansing using the gentle and light baby bath soap, a pedicure if the respondents have long nails, cutting and scraping their nails and a foot mask by applying a scrub to clean off the dead skin cells. However, this cannot be done every day due to avoiding the skin from becoming slighter. A foot massage is a superficial massage of the foot for the purpose of increasing the circulation of the blood. The last step is applying a moisturizing cream to the skin. This is useful for avoiding dry skin. The diabetic foot spa was done \pm 30 minutes over 3 days consecutively in the group treatment (Wardani, et al., 2019).

The implementation of the spa for diabetic feet began with diabetic foot exercises with the aim of making the blood circulation smooth. The activity is then continued by soaking the feet in warm water at a temperature of $40-41^{\circ} \mathrm{C}$. Moreover, a sphygmomanometer was used to measure the Ankle Brachial Index score. Foot sensitivity was measured using a cotton and hammer, scratched on the sole of the foot. Glucose level was measured using a glucometer. The data analysis used for the blood glucose level was a t test. The data from the sensitivity and ABI score were measured using the Wilcoxon sign rank test. This research had ethical clearence and it was conducted in Unusa, No. 183/EC/KEPK/UNUSA/2018.

\section{RESULTS}

Table 1 shows that of the distribution respondents from the group, most of them $(56,6 \%)$ were $56-65$ years old, female $(66,6 \%)$ and occupation as traders (70\%).

The mean score of Anckle Branchial Index before the intervention was 3.23 , after the intervention showed an increase of 3.77 . The mean value of foot sensitivity before the intervention shows 2.5 , this value has increased after getting intervention that is equal to 3, while the average value of Blood Glucose level, has decreased, before the intervention shows 
Table 1. Frequency Distribution of Age, Gender and Profession $(\mathrm{n}=30)$

\begin{tabular}{lcc}
\hline Demographic Data & $\mathbf{n}$ & $\mathbf{\%}$ \\
\hline Age & & \\
$36-45$ & 0 & 0 \\
$46-55$ & 13 & $43, .4$ \\
$56-65$ & 17 & 56.6 \\
Gender & & \\
Male & 10 & 33.4 \\
Female & 20 & 66.6 \\
Occupation & & \\
$\quad$ Unemployed & 6 & 20 \\
$\quad$ Government Employees & 1 & 3.4 \\
$\quad$ Traders & 21 & 70 \\
$\quad$ House work assistance & 2 & 6.6 \\
$\quad$ Security & 0 & 0 \\
\hline
\end{tabular}

the number 289.23 after being given an intervention of 124.57. The results of this study indicate that the diabetic foot spa has a significant effect on the Anckle Branchial Index $(p=0.001)$, Foot Sensitivity ( $p$ $=0.001)$ and Blood Glucose Levels $(\mathrm{p}=0.001)$ (Table 2).

\section{DISCUSSION}

The activities not only improve blood flow but they also make the patients feel comfortable and relaxed. Diabetic foot exercise is an effective way to improve the ABI score. Foot exercises are a way to improve circulation, especially of the feet. Foot exercises, which are an aerobic, are focused on the movement variations in the foot area that meet the criteria of continuous, rhythmical, interval, progressive and focused on endurance. Each step should be done completely (Wahyuni, 2013). The recommended exercise for DM patients is aerobics, meaning that it needs oxygen that can help the circulation of the blood, to strengthen the main muscles of the foot, to prevent the foot deformities that can reduce the potential of diabetic foot wound and to improve the insulin production used for glucose transport to the cells. This can help to reduce the level of blood glucose (Dewi, et al., 2012).

During the skin cleansing, the client's feet are soaked in warm water at a temperature of $41-420 \mathrm{C}$. According to the research of Suandika, soaking the feet in to warm water at a certain temperature can improve the blood circulation, reduce edema and increase the circulation to promote muscle relaxation. The heat of the warm water can cause blood vessel dilation which leads to an improvement in blood circulation (Suandika, 2016) and release pain (Zahroh \& Faiza, 2018).

Through foot exercise therapy and soaking the feet in warm water, this activity also increases the ABI score. The nerve point of people with type 2 Diabetes Mellitus is the pancreas. This is a pancreatic point closely related to the hormone insulin which affects the blood levels in the body (Ruben, et al., 2016).
Emphasizing the point of reflection on the foot with that of the pancreas, it is located on both the right and left sides of the foot. The inside of the nerve receptors will work and the stimulation will turn into electricity or bioelectrics. This will spread to the brain and start in the pancreas, thereby increasing the hormone insulin. This allows the calcium levels in the blood to become balanced.

In this study, we also added massage to the points between the thumb and forefinger of the foot (Mahendra, et al., 2008). The emphasis is on repetition focused on the area of the foot reflection points which also makes the blood circulation system become smooth because of the bioelectricity stimulation. This helps to destroy clots in the bloodstream, thus helping to neutralize the excessive carbohydrates in the blood. This will lead to the improvement of the ABI. In this study, the researcher used an acupressure technique 30 times with a clockwise emphasizes (Mahendra, et al., 2008).

Based on the research above, it is shown that the ABI of a person with DM can be controlled and enhanced by doing the aforementioned activities, especially focused on the movements of the foot. The activities should be done regularly in a measured manner, in addition to properly and correctly. A diabetic foot spa activity that is done seriously will stimulate the blood vessels to circulate smoothly which is shown by the perspiration on the body. This can increase the insulin production of the pancreas, thus improving the ankle brachial index score (Wardani, et al., 2019).

It is shown that the blood glucose levels of a person with Diabetes Mellitus can be controlled or reduced by using such energy in an activity. Diabetic foot prevention cannot be separated from general disease control including blood glucose level control, nutritional status, blood pressure, cholesterol level and a healthy lifestyle. If the foot sensitivity is not continuously kept in a good condition, then it is likely that people with diabetes will experience diabetic foot disorders. This increases the risk of amputation and even the risk of death. This therapy can increase the sensitivity and circulation of the foot.

The foot spa affects the decrease in blood sugar levels and it can increase the sensitivity of the foot. This research has positive implications. That is, it can have an impact related to increasing the sensitivity of the foot when it is done within 2 weeks properly and according to the SOP spa guidelines for diabetic feet.

Puskesmas nurses should be given training through Training of Trainer (TOT). Monitoring the effectiveness of the interventions and providing motivation can be carried out by the cadres in each 
Table 2. The dispute of the ankle brachial index, foot sensitivity, and. the blood glucose levels before and after the intervention of diabetic foot spa $(n=30)$

\begin{tabular}{lcccc}
\hline Variable & Mean & Std. Deviation & Std. Error Mean & p-Value \\
\hline Ankle Brachial Index & & & & 0.001 \\
$\quad$ Pre-test & 3.23 & 0.817 & 0.149 & \\
$\quad$ Post-test & 3.77 & 0.430 & 0.079 & 0.001 \\
Foot Sensitivity & & & 0.115 \\
$\quad$ Pre-test & 2.50 & 0.630 & 0.000 & 0.001 \\
$\quad$ Post-test & 3.00 & 0.000 & & \\
Blood Glucose Levels & & & & \\
$\quad$ Pre-test & 289.23 & 99.524 & 6.035 & \\
$\quad$ Post-test & 124.57 & 33.056 & & \\
\hline
\end{tabular}

region. The Health Service places nurses in the Puskemas with a minimum education level of a Bachelor's of Nursing. They strive to have specialist nurses that are responsible for developing and managing non-communicable diseases control programs, especially Diabetes Mellitus, through empowering programs and developing diabetic foot spa center (Jansink, 2010).

The scope of nursing education in terms of community service assists in managing health problems, especially Diabetes Mellitus, by the means of students being equipped with how to properly practice diabetic foot spa. Therefore, health education is important when it comes to providing nursing care to people with Diabetes Mellitus due to their limited ability, including the prevention of the risk of injury due to diabetes.

The limitation of this study was not examining the characteristics of the respondents who may have a relationship with foot sensitivity and/or blood sugar levels. The characteristics that were not examined include culture, the consumption of food that is carried out, the daily activities undertaken and the patient's compliance with carrying out the therapies recommended by doctors, nurses and other health professionals.

\section{CONCLUSION}

A foot spa is an intervention which it is carried out regularly and independently. This will result in the tingling sensation and pain in the feet being reduced. Moreover, these problems can be removed and the patients can avoid complications such as ulcerations and amputation.

\section{REFERENCES}

Bistara, D. N. \& Ainiyah, N., 2017. Hubungan pengetahuan dengan kepatuhan diet pada penderita diabetes mellitus di Posuandu Lansia Cempaka Kelurahan Tembok. Journal of Health Sciences, 11(1), pp. 51-57. https://doi.org/10.33086/jhs.v11i1.117
Bistara, D. N., Zahroh, C. \& Wardani, E. M., 2019. Tingkat stress dengan peningkatan kadar gula darah pada penderita diabetes mellitus. Jurnal Ilmiah Keperawatan, 5(1), pp. 77-82.

Black, J. \& Hawks, J., 2014. Keperawatan Medikal Bedah. Jakarta: Salemba Emban Patria.

Dewi, P., Sumarni, T. \& Sundari, R., 2012. Pengaruh senam diabetes mellitus dengan nilai ABI (Ankle brachial index) pada pasien diabetes mellitus di Puskesmas Padamara Purbalingga. Jurnal Stikes Harapan Bunda, Volume 5, pp. 1-6.

Eraydin, S. \& Avsar, G., 2017. The effect of foot excercise on wound healing in type II diabetic patients with a foot ulcer. Journal Wound Ostomy Continence Nurs, 45(2), pp. 123-130. doi: 10.1097/WON.0000000000000405

Ganong, W. F., 2008. Fisiologi Kedokteran. Jakarta: EGC.

Greenstein, B. \& Wood, D., 2010. At a Glance System Endocrine. Jakarta: Erlangga.

IDF, 2013. International Deabetes Mellitus Atlas. USA: IDF.

Jansink, R., 2010. Primary care nurses struggle with lifestyle counseling in diabetes care. BMC family practice, 11(1), p. 41. https://dx.doi.org/10.1186\%2F1471-2296$11-41$

Mahendra, B., Kruinastuti, D., Tobing, A. \& Alting, B. Z., 2008. Care yourself diabetes mellitus. Jakarta: Penebar Plus.

Mahfud, M., 2012. Hubungan perawatan kaki pasien diabetes mellitus tipe II dengan kejadian ulkus diabetik di RSUD Dr. Muwardi. Surakarta: Fakultas Kedokteran Universitas Muhammadiyah Surakarta.

PERKENI, 2011. Konsensus pengelolaan dan pencegahan diabetes mellitus tipe $2 \mathrm{di}$ Indonesia. Jakarta: Perkeni. 
Purwanti, 0., 2013. Analisis faktor risiko terjadi ulkus kaki pada pasien diabetes mellitus di RSUD dr. Muwardi. Jakarta: Fakultas Kedokteran Universitas Indonesia.

Riskesdas, 2018. Laporan Hasil Riset Kesehatan Dasar Nasional 2018. Jakarta: Badan Penelitian dan Pengembangan Kesehatan Departemen Kesehatan RI.

Ruben, G., Rottie, J. v. \& Karundeng, M. Y., 2016. Pengaruh senam kaki diabetes terhadap perubahan kadar gula darah pada pasien diabetes mellitus tipe 2 di wilayah kerja Puskesmas Enemawira. eJurnal Keperawatan, $4(1)$.

Smeltzer, S. \& Bare, B., 2001. Buku Ajar Keperawatan Medikal Bedah. Jakarta: EGC.

Suandika, M., 2016. Pengaruh rendam kaki air hangat terhadap peningkatan sirkulasi darah perifer dilihat dari ankle brachial ind ex (ABI) pada pasien diabetes mellitus di Desa Purwojati. Medisains, 14(1).

Tang, Z.-H., Fang, Z. \& Zhou, L., 2013. Human genetic of diabetic vascular complications.
Journal of Genetics, 92(3), pp. 677-694. https://doi.org/10.1007/s12041-013-02881

Wahyuni, T., 2013. Ankle brachial index sesudah senam kaki diabtes pada penderita diabetes mellitus tipe II. Jurnal Keperawatan, 4(2).

Wardani, E. M., Wijayanti, L. \& Ainiyah, N., 2019. The effect of diabetic foot spa on ancle brachial index and foot sensitivity of diabetes mellitu type 2. Jurnal Keperawatan Respati Yogyakarta, 6(3), pp. 672-676. https://doi.org/10.35842/jkry.v6i3.391

Windasari, N., 2015. Pendidikan kesehatan dalam meningkatan kepatuhan merawat kaki pada pasien diabetes mellitus tipe II. Muhammadiyah Journal of Nursing, 2(1), pp. 79-90.

Zahroh, C. \& Faiza, K., 2018. Pengaruh kompres hangat terhadap penurunan nyeri pada penderita penyakit arthtitis gout. Journal of Ners and Midwifery, 5(3), pp. 182-187. https://doi.org/10.26699/jnk.v5i3.ART.p18 2-187 